\title{
HOLISTIC IMPLEMENTATION OF KNOWLEDGE OF THE MARKETING AMBASSADORS
}

Purpose - The paper emphasizes the role of marketing knowledge in development of countries, organizations, schools and universities. The purpose is a research on the power of knowledge of the marketing ambassadors and proposal of a model for holistic implementation of knowledge of the marketing ambassadors.

Methodology - Using a face-to-face questionnaire interview, the study was conducted on a sample of 30 marketing managers, 10 employees in government, 10 professors and 10 students in doctoral studies in Serbia.

Findings - The marketing ambassadors - professors, students, practitioners, government, ministers and all employees in the field of marketing, with their marketing knowledge and skills, can contribute to the development of schools, universities, organizations and countries.

Practical implications - There is a need to create, exchange and implement marketing knowledge on all levels - starting from schools and universities, through organisations, all the way to the ministries of the government. The marketing ambassadors, on the basis of common activities (e.g. projects) can contribute to the creation, implementation and exchange of marketing knowledge, to the positive results on certain levels and to country development.

Originality/value - The paper promotes holistic approach to creation and exchange of knowledge.

Key words: marketing, marketing knowledge, marketing ambassadors, holistic marketing

\section{Introduction}

"Knowledge is power" - Sir Francis Bacon realized some 400 years ago. "The knowledge-based view of the firm suggests that knowledge creation and management are key in today's knowledge intensive society". 'Given the necessity, importance and influence of knowledge and changes, the paper emphasizes

Professor Beba Rakic, PhD, Graduate School of Business Studies, Megatrend University, Belgrade, e-mail: brakic@megatrend.edu.rs

** Professor Mira Rakic, PhD,Graduate School of Business Studies, Megatrend University, Belgrade, e-mail: mrakic@megatrend.edu.rs

1 Hanvanich Sangphet, Dröge Cornelia, Calantone Roger (2003): "Reconceptualizing the meaning and domain of marketing knowledge", Journal of Knowledge Management, 7(4): 124. 
the role of economic and especially marketing knowledge. Implementation of marketing knowledge is necessary at the level of countries, organizations and schools/universities.

The paper focuses on the effects of implementation of marketing decisions by the main actors, which Figure 1 summarizes. Main actors - ambassadors in the creation, implementation and transfer of marketing knowledge are the professors, students, practitioners, government ministers and all employees in the field of marketing.

Figure 1: Model: Effects of implementation of knowledge of the marketing ambassadors - "the snowball effect"

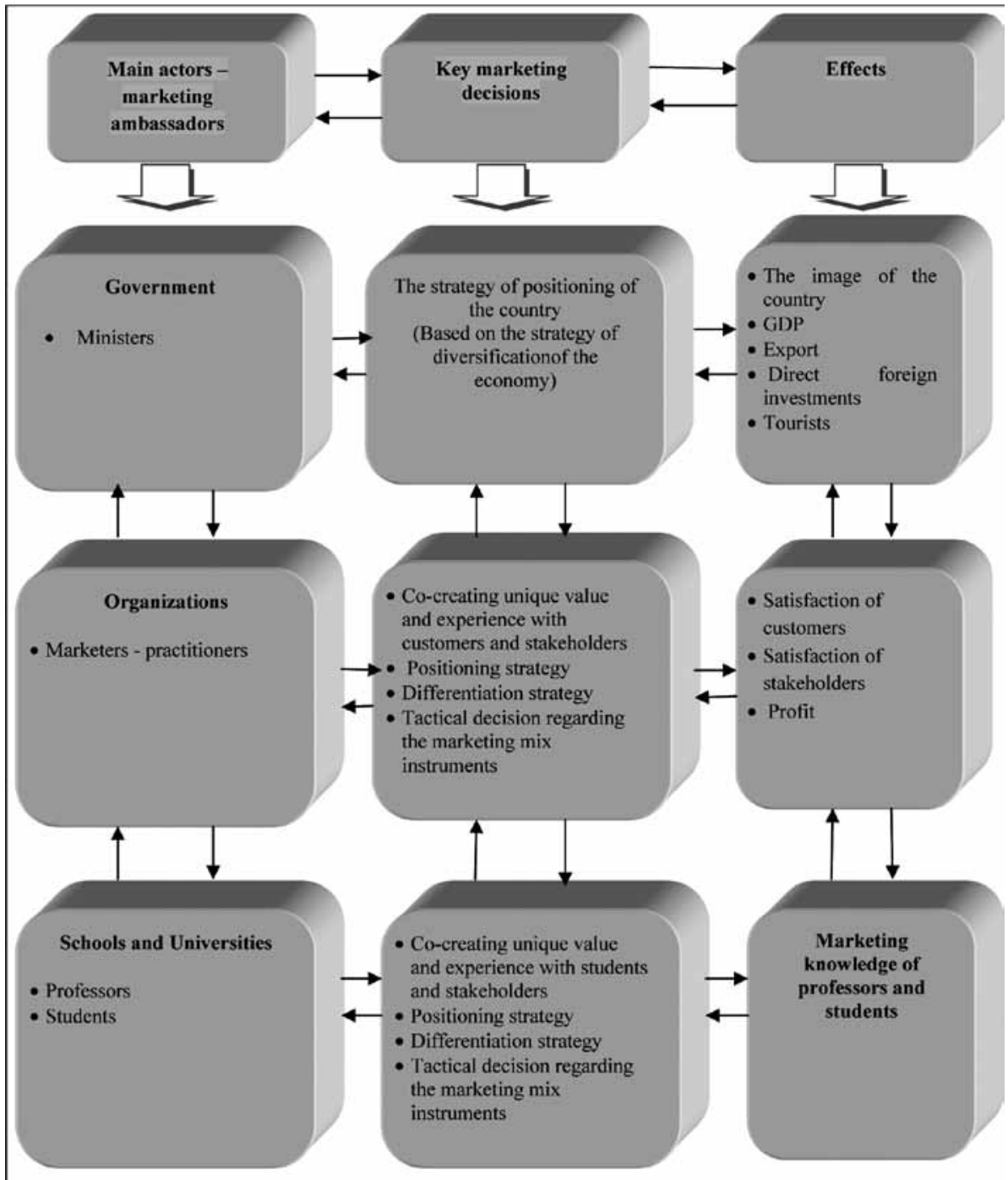


Gross Domestic Product (total and per capita), positioning of the country and the organization depends on the integrated action of all stakeholders, acceptance and implementation of marketing at all levels. Who should participate in the marketing evolution of a country? The answer is: government ministers, professors and students in schools and universities; practitioners - leaders, managers and skilled employees in the organizations and citizens of countries. How? Government ministries - with definition and implementation of positioning strategy; professors in schools and universities - with theoretical and practical contribution to the development of marketing; practitioners - leaders, managers and skilled employees in the organization - with implementation of marketing in everyday business. ${ }^{2}$

\section{Theoretical foundations and development hypotheses}

\subsection{Holistic implementation of knowledge of the marketing ambassadors}

In marketing literature and business, a difference is made between professors and practitioners, as well as between the knowledge of professors and practitioners. Wierenga ${ }^{3}$ makes a difference between academic and practitioner marketing knowledge. Schools and universities should be a basis for the creation of knowledge. And is it so? Is the knowledge of professors needed for students who are becoming marketing practitioners? The literature suggests that the knowledge of academics and business schools is insufficient. ${ }^{4} / /^{5} / 7^{7} / 8$ Academics are in the knowledge creation and dissemination business. But have marketing academics fallen into the trap that Levitt ${ }^{9}$ so cogently describes in his famous Mar-

2 Rakić Mira, Rakić Beba (2014): “Integrated marketing r (e)volution in Serbia”, Conference proceedings: SMEs development and innovation: building competitive future of SouthEastern Europe, International conference - SMEs development and innovation: building competitive future of South-Eastern Europe, Faculty of economy - Prilep, Ohrid.

$3 \quad$ Wierenga Berend (2002): “On academic marketing knowledge and marketing knowledge that marketing managers use for decision-making”, Marketing Theory, 2(4): 355-362.

4 Ankers Paul, Brennan Ross (2002): „Managerial relevance in academic reserach: an exploratory study”, Marketing Intelligence \& Planning 20(1), 15-21.

5 Bennis Warren, O’Toole James (2005): “How business schools lost their way", Harvard Business Review, 83(5): 96-104.

6 Dibb Sally, Simkin Lyndon (2003): "Marketing educators: addressing implementation in core courses", Journal of Strategic Marketing, 11(1): 3-13.

$7 \quad$ Lee Hanjoon, Acito Frank, Day Ralph (1987): "Evaluation and use of marketing research by decision makers: a behavioral simulation", Journal of Marketing Research, 24(2): 187-196.

$8 \quad$ November Peter (2008): “Marketing knowledge myopia”, European Business Review, 20(5): 434-456.

$9 \quad$ Levitt Theodore (1960): “Marketing myopia”, Harvard Business Review, 38(4): 45-56. 
keting Myopia, of focusing on the product and how it is produced rather than on the needs of the customer? ${ }^{10}$ November ${ }^{11}$ in the article: "Marketing Knowledge Myopia”, gave an affirmative answer to the posted question - „marketing academics have become myopic as to what marketing knowledge is, and they have become product-oriented, with the objective of producing as much of it as." According to Ottesen and Gronhaug, "academic marketing knowledge is only to a limited degree utilized in practical life" and "that the use of scientific marketing knowledge can be highly valuable to practitioners - but also that intended users typically do not exploit such knowledge". "However, even if a marketing manager could be aware of all the achievements of academic research in marketing, this would definitely not be sufficient for the manager's decision-making". ${ }^{13}$ Gronhaug $^{14}$ emphasized that "academian marketing knowledge can be useful, requiring, however, both knowledge, time-consuming and motivated efforts." With regard to holistic approach to the creation of marketing knowledge, in this paper, within the marketing ambassadors beside professors and practitioners, students and representatives of the government ministries stand out. In time, students become professors or practitioners. Representatives of the government ministries by their activities and laws can influence both professors and practitioners. The importance lies primarily on the government ministries, which have been oriented (i.e. which should be oriented) towards defining and implementation of the strategy of the country positioning.

Marketing skills are one of the key bases for the development of countries and organisations. Creation, development and implementation of marketing knowledge are needed at all levels. Figure 1 shows the effects of implementation of marketing decisions by main actors. The main actors - ambassadors make appropriate marketing decisions that have certain non-financial and financial effects, and the effects in return influence main actors and further decisions. All main actors are interrelated and they affect the final results together. The basis is the marketing knowledge which is acquired (or at least which should be acquired) in schools and universities. Marketing knowledge of the professors is transmitted and increased (or at least it should be like that) like the "snowball" to students, employees in different organizations, including government. Therefore, marketing knowledge is transferred like 'a rolling snowball' among the marketing ambassadors on the government level, among organisations, schools and universities. Thus the first hypothesis was proposed:

$10 \quad$ November Peter (2008): “Marketing knowledge myopia”, European Business Review, 20(5): 434.

11 Ibid, 434.

12 Ottesen Geir, Gronhaug Kjell (2004): "Barriers to practical use of academic marketing knowledge", Marketing Intelligence \& Planning, 22(5): 526.

13 Wierenga Berend (2002): “On academic marketing knowledge and marketing knowledge that marketing managers use for decision-making", Marketing Theory, 2(4): 357.

14 Gronhaug Kjell (2002): "Is marketing knowledge useful”, European Journal of Marketing, 36 (3): $364-372$. 
Hypothesis 1. There is positive relationship between the marketing knowledge of the marketing ambassadors and marketing decisions and results.

In digital landscape, changes are constant. Marketing knowledge and decisions of actors should also be harmonised. The changes of marketing decisions among actors mutually and all together integrally - influence the changes on the level of country, organisations, schools and universities. Therefore, the implementation of marketing knowledge at the level of country, organisations, schools and universities can influence the country development. The following hypothesis was thus proposed:

Hypothesis 2. There is a positive relationship between the marketing knowledge of the marketing ambassadors and country development.

\subsection{Marketing activities at the level of government}

The key strategies of the government of a country are related to the diversification of the economy (according to the sources of competitive advantage) and positioning the country. ${ }^{15} / 16 /{ }^{17} / 18 / 19 / 20 / 21$ The results are: the image of the country, GDP, exports, direct foreign investment and tourists. The implementation of integrated economic knowledge at the level of government should provide:

- defining and implementation of development strategies of diversified economy,

- defining and implementation of an integrated strategy of positioning the country,

- creating and maintaining a favorable image of the country,

- creating conditions for increasing direct foreign investments,

- increase of exports,

- encouraging the implementation of marketing in organizations,

- as a result of previous activities - increasing employment, production, GDP, investment; income, purchasing power and savings of population and reduction of poverty.

15 Anholt Somon (2005a): “Editor's foreword”, Place Branding 1(4), 333-346.

16 Anholt Somon (2005b): "Plug into your national brand", International Trade Forum, 20-23.

17 Anholt Somon (2007): “The Anholt Nation Brand Index - Special Report Q2", GMI.

18 Brodie Roderick, Sharma, Rahul (2011): "National branding for New Zealand Exports", Marketing Theory, 14(1): 7-17.

19 Gilmore F. (2002): “A country - can it be repositioned? Spain - the success story of country branding", Journal of Brand management, 9(4-5): 281-293.

20 Kotler Philip, Gertner David (2002): "Country as brand, product, and beyond: a place marketing and brand management perspective", Brand Management, 9(4-5): 249-261.

21 Reinert Erik (2006): Globalna ekonomija - Kako su bogati postali bogati i zašto siromašni postaju siromašniji, Beograd: Čigoja štampa. 
Increase in GDP and the income of population enable new investments in education and the economy, which leads to further reduction of poverty (of the country, families and individuals).

Reinert in his book: The global economy - How the rich became rich and why the poor become poorer - presents a problem of undiversification of economy of the underdeveloped - poor countries and the reliance on single or small number of branches (activities) in its development (most commonly in agriculture). "Globalization, as it has been happening in the world in the last 20 years, caused the disappearance of the industry in many poor countries, and they returned to the stage dominated by the law of decreasing income. Global sustainable development will depend on the poor countries to develop industries and thus create alternative employment outside the economic activities based on natural resources". ${ }^{22}$ It is believed that poverty in developing countries, regardless of region, is a consequence of low levels of economic development and/or inadequate economic and social policies for poverty reduction. ${ }^{23}$

The concept of positioning does not apply only to products, but also to the country. Positioning strategies are crucial for the survival of countries. Numerous authors talk about the significance and influence of country positioning on competitive advantage over other countries. The positioning of the country is creating a specific country's position in the minds of potential consumers, tourists, investors and other relevant groups. Countries apply the means of marketing management and positioning because they need to attract tourists, companies (direct investments) and talented people and to export. Countries compete with each other and try to provide sources of competitive advantage on the global marketplace. ${ }^{24}$ Countries compete among themselves for the buyers of their products, tourists, investments and image.

The basics of positioning and the factors that influence the image of the country are: exports, government, culture and heritage, people, tourism and investments and immigration. ${ }^{25}$ These bases have complementary effect to the integrated positioning of the country. Creating and exporting the famous brand name products is an important basis for positioning the country. The countries with the best brands are also the richest countries - which have the highest GDP. ${ }^{26}$ Therefore, for successful export and GDP growth, it is necessary to build brands on the international - global market. Good image and positioning of the

$22 \quad$ Ibid, 64.

23 Hirono Ryokichi (2003): "Reorienting international development to accelerate poverty reduction and ensure sustainability as this century's top development goals", International Review for Environmental Strategies, 4(1): 21-44.

$24 \quad$ Kotler Philip, Gertner David (2002): “Country as brand, product, and beyond: a place marketing and brand management perspective", Brand Management, 9(4-5): 249-261.

25 Anholt Somon (2007): “The Anholt Nation Brand Index - Special Report Q2", GMI.

26 Anholt Somon (2005a): “Editor's foreword”, Place Branding 1(4), 333-346. 
country affect the acceptance of foreign brands on the market. A country can be positioned on the basis of a competent government that makes responsible decisions which support international peace and security, and by emphasis on government's behaviour which is consistent with the global environment and reduction of poverty. The country can further position itself on the basis of cultural heritage and contemporary culture - movies, music, art and literature. People - kindness of residents and expertise (human capital) are important basics of positioning the country. Tourism is often the most visible aspect of the promotion of the country. Natural beauty, heritage and other segments of the tourist potential are the basics of positioning the country. Investments are needed in order to achieve the benefits of tourism. Despite the importance of tourism, the country can not expect the revenue from tourism to solve all problems. On the contrary, the country must first solve its own problems so that it could have a desired income from tourism. Country can be positioned on the basis of investment opportunities (for business people) and immigration - living and working in the country (for students and professionals). In general, people are mostly attracted to countries that are based on clear, consistent messages about the qualities which people value, such as a competent government, friendly people and economic opportunities. ${ }^{27}$

The image of the country is the result of economic, geographic features, history, art and music, the image of the famous people and other characteristics. ${ }^{28}$ The image of the country of origin and the perception of residents of other countries about the strength of the observed country in terms of science and technology, affect the export (from the observed country). The image of the country of origin affects consumers' willingness to actively explore or avoid products of certain countries. ${ }^{29}$ The research results confirm that $70 \%$ of companies believe that the image of the country of origin significantly influences consumers' decisions to buy products. There are many stereotypes about countries that aim to consumers' perceptions, for example, German engineering, French style, Italian food, etc. ${ }^{30}$ Thus, consumers have some idea and perception about the countries that affect their buying decisions, regardless of whether the country has and implements a strategy of positioning. It is necessary to study the current image and the change in the direction of creating and maintaining a desired image.

Positioning of the country, creating and maintaining the desired image is a continuous process which should be engaged by various actors at all levels from government, through organizations to individuals - leaders, managers, employees and citizens. Such considerations suggest the following hypothesis:

27 Anholt Somon (2007): “The Anholt Nation Brand Index - Special Report Q2”, GMI.

28 Anholt Somon (2005b): "Plug into your national brand", International Trade Forum, 20-23.

29 Anholt Somon (2007): “The Anholt Nation Brand Index - Special Report Q2”, GMI.

30 Sorrell Martin (2002): “Branding the nation”, Brand Strategy, 25(159): 13. 
Hypothesis 3. There is a positive relationship between the marketing knowledge of the government and marketing decisions and results (of the government).

\subsection{Marketing orientation of organizations}

A marketing orientation is needed at all levels - ranging from any profitoriented, non-profit organization, via municipalities and cities/towns to the gov

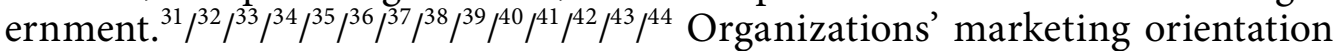
leads to profitable business operations. Profitable marketing is defined as profitable satisfaction of the consumer's needs, i.e. the creation and maintenance of the consumer and the profit. Of course, a question is raised as to how we shall create and maintain the consumer and the profit as well. A simple answer to that question would be: it is "only" needed to do business with market mindset. The basis is a market-oriented organisation in which all employees "think with

$31 \quad$ Blocker Christopher et. Al. (2011): "Proactive customer orientation and its role for creating customer value in global markets", Journal of the Academy of Marketing Science, 39(2): 216-233.

32 Foley Anthony, Fahy John (2009): "Seeing market orientation through a capabilities lens", European Journal of Marketing, 43(1-2): 13-20.

33 Kohli Ajay, Jaworski Bernard (1990): "Market orientation: the construct, research propositions and managerial implications”, Journal of Marketing, 54(2): 1-18.

34 Lafferty Barbara, Hult Tomas (2001): "A synthesis of contemporary market orientation", European Journal of Marketing, 35(1-2): 92-109.

35 Levitt Theodore (1960): "Marketing myopia”, Harvard Business Review, 38(4): 45-56.

36 Narver John, Stanley Slater (1990): “The effect of a market orientation on business profitability", Journal of Marketing, 54(4): 20-35.

37 Osborne Phil, Ballantyne David (2012): “The paradigmatic pitfalls of customer-centric marketing”, Journal of Marketing Theory \& Practice, 12(2): 155-172.

38 Raaij Erik, Stoelhorst J.W. (2008): “The implementation of a market orientation: A review and integration of the contributions to date", European Journal of Marketing, 42(11-12): 1265-1293.

39 Vasiljev Stevan, Salai Suzana (2000): “Marketing kao ključna komponenta poslovnog potencijala”, Strategijski menadžment, 4(1): 38-43.

40 Filipović Vinka (1994): “Marketing i upravljanje sistemom kvaliteta”, Marketing, 25(4):57-62.

41 Žnideršić-Kovač Ružica, Marić Dražen, Salai Suzana, Grubor Aleksandar (2013): "Etičko ponašanje potrošača u marketingu”, Anali Ekonomskog fakulteta u Subotici, 29: 65-79.

42 Barac Nada (1994): "Marketing logistika i informacioni i komunikacioni sistemi", Ekonomika, 40(5): 54-60.

43 Milisavljević Momčilo (2005): “Tržišna orijentacija i poslovni uspeh preduzeća”, Megatrend revija, 2(2): 151-165.

44 Buha Vesna, Janičić Radmila, Filipović Vinka, Gligorijević Mirjana (2011): “Virtuelna realnost u obrazovanju na daljinu i marketinškim komunikacijama", Management časopis za teoriju i praksu menadžmenta, 16(60): 51-59. 
market mindset" (i.e. they understand the necessity and importance of researching into and profitably satisfying the consumer's needs and continual integrated communications with them). Levitt in his article on marketing myopia, concludes that organizations must realize that they are not engaged in manufacturing of products but "buying of customers" (and we could add relationships with other key business partners) and activities affecting the partners to want to do business with the organization. In other words, Levitt stressed the importance of effectiveness in relation to efficiency, as well as the necessity and importance of managing relations with customers and business partners. ${ }^{45}$

Traditional transactional marketing (also known by " $4 \mathrm{P}$ " - four instruments of marketing mix) is considered insufficient in the current business environment. The value is not in the marketing mix. The value is in creating, developing and maintaining relations with customers and other partners. ${ }^{46} /{ }^{47} / 48 /{ }^{49} / 50$ Due to environmental changes, the relational marketing is of the particular importance, i.e. creating, developing and maintaining relations with customers and business partners. Managers emphasize relationship management both internally with employees and externally with customers, suppliers, distributors and other relevant partners. Relational marketing is based on good communication. ${ }^{51}$ In the network world, more money can be made on the basis of managing interactions, rather than execution of activities. ${ }^{52}$

The influence of consumers on marketing management of organizations is changing - from the traditional system of value creation for consumers to co-creation of unique values with consumers. ${ }^{53} / 5^{54}$ Two paradoxes describe the

45 Levitt Theodore (1960): "Marketing myopia", Harvard Business Review, 38(4): 45-56.

46 Brodie Roderick, Coviello Nicole, Bliemel Friedhelm (2003): "Introduction to the Special Issue on Conceptual Developments in Relationship Marketing", Marketing Theory, 3(1): 5-7.

47 Durme Joel, Brodie Roderick, Redmore David (2003): "Brand Equity in Cooperative Business Relationships: Exploring the Development of a Conceptual Model”, Marketing Theory, 3(1): 37-57.

48 Grönroos Christian (1997): "From marketing mix to relationship marketing - towards a paradigm shift in marketing", Management Decision, 35(3-4): 322-339.

49 Pels Jaqueline, Coviello Nicole, Brodie Roderick (2000): "Integrating transactional and relational marketing exchange: a pluralistic perspective", Marketing Theory, 8(3): 11-19.

50 Plewa Carolin, Quester Pascale, Baaken Thomas (2005): "Relationship marketing and university-industry linkages: A conceptual framework", Marketing Theory, 5(4): 443-456.

$51 \quad$ Feiertag Howard (1997): "Relationship selling works only when practiced", Hotel \& Motel Management, 212(6): 18.

52 Sawhney Mohanbir, Parikh Deval (2001): "Where value lives in a networked world", Harvard Business Review, 79(1): 79-86.

53 Pongsakornrungsilp Siwarit, Schroeder Jonathan (2011): "Understanding value co-creation in a co-consuming brand community", Marketing Theory, 11(3): 303-324.

54 Prahalad C.K., Ramaswamy Venkatram (2004): The future of competition - co-creating unique value with customers, Boston: Harvard Business School Publishing. 
economy at the beginning of the 21st century. Consumers have more choices that contribute to lower satisfaction. Top management has more strategic options that contribute to a lower value. What is stated encourages reconsideration of the traditional value system. Leaders need new frames of reference for value creation. The solution is a concept of co-creating an unique value with customers. Thanks to the Internet, consumers can connect and engage in active dialogue with manufacturers of products/services. Instead of producers, consumers initiate and control the dialogue with producers. The market becomes a forum where consumers play an active role in creating the value. An important feature of the new market is that consumers are becoming a new source of competence for the organization. Competence of consumers depends on their knowledge and skills, willingness to learn and experiment and the ability to participate in an active dialogue. Given the new role of consumers, competence is a function of the collective knowledge available in the entire system, i.e. expanded network made up of consumers, the traditional suppliers, manufacturers, investors and other business partners. The role of consumers is changing. Organizations can no longer act autonomously, design products, develop manufacturing processes, determine pricing, create marketing messages and control the distribution channels without the affect of the consumers. Consumers tend to affect every part of the business system. Trained with new tools and dissatisfied with the existing choices, consumers want to influence and participate in the co-creation of value with the organization. Interaction is the basis of a new system of co-creation of the unique value $.{ }^{55} / 56 / 57$

Implementation of marketing at level of organization means faster and more profitable production of products/services in relation to national and/or foreign competitors. Organizations must produce competitive products (lowest cost and/ or differentiated products) in accordance with the requirements of consumers. Given the growing global competition, we could say that, for the competitive advantage, it is not enough to produce and sell products at lowest prices, it is necessary to offer differentiated products, often at lower prices, faster than the national and/or global competitors. Nowadays, in digital landscape, the engagement and co-creating unique value with customers are required. In other words, the main sources of competitive advantage of organizations are: speed, engagement with customers, low cost of products/services and innovation.

The implementation of integrated knowledge at the level of organization should provide:

\footnotetext{
$55 \quad$ Prahalad C.K., Krishnan M.S. (2008): The new age of innovation - driving co-created value through global networks. USA: McGraw Hill.

56 Prahalad C.K., Ramaswamy Venkatram (1999): Co-opting customer competence", Harvard Business Review, 78(1): 79-87.

57 Prahalad C.K., Ramaswamy Venkatram (2004): The future of competition - co-creating unique value with customers, Boston: Harvard Business School Publishing.
} 
- determination of the current position of the organization in competitive environment,

- marketing orientation of organizations,

- (re)positioning of organizations,

- as a result of previous activities - profit of organizations, customers' satisfaction and sustainable development.

Increase of profit of organizations affects on the increase of individuals' incomes, GDP and opportunities in terms of new investments (in education and the economy).

To explore this issue, the following hypothesis is tested:

Hypothesis 4. There is a positive relationship between the marketing knowledge of the organisations and marketing decisions and results (of the organisations).

\subsection{The role of schools and universities}

In addition to governments and organizations, the key stakeholders in the process of creating, transfer and implementation of knowledge are the schools and universities. Key marketing decisions of the schools and universities are: co-creation of unique value with students, their parents and stakeholders; positioning and differentiation of services and universities; the tactical decisions on marketing mix instruments. The result is the marketing knowledge of marketing ambassadors - professors, practitioners, students and all employees in the field of marketing.

Integrated - theoretical and practical knowledge is the result of the complementary effects of multiple disciplines, subjects and methods; knowledge and interactions between professors, practitioners, students and all employees in the field of marketing. A method of teaching is required, effective for learning theoretical concepts and principles, but it is not enough. In order for students to apply the acquired theoretical concepts, case studies should be used in teaching. The involvement of students in organizations ('practice') during their studies is of particular importance. Schools and universities are able to:

- prepare and implement modern programs and methods, which enable the creation of theoretical and practical knowledge necessary for the development of individuals, organizations and countries;

- have their own business, institute, or to conduct researches for other organizations (profit, nonprofit, government, etc..), be engaged in consulting and etc.;

- $\quad$ engage students (in the implementation of additional activities);

- and/or establish and maintain contact with other organizations in which students acquire additional - practical knowledge; 
- educate employees in organizations (e.g. through seminars, webinars, creative workshops, etc).;

- and in the previously mentioned ways, provide their students with the acquisition of integrated knowledge;

- establish and maintain contact between professors, students and practitioners - schools, universities and organizations - in order to develop individuals, organizations and economy of the contry.

With acquisition of theoretical and practical knowledge, graduate students are prepared to solve multidisciplinary issues of organization and/or economy. The above mentioned contributes to the positioning and differentiation of schools, universities, organizations, economy and country. To define and implement innovative curricula and methods, it is necessary to have: leaders ( rectors, vice rectors, deans, professors, etc..) with a vision, who have the knowledge, power and desire to direct faculties and students, professional and motivated professors, money and time. ${ }^{58}$ This implies:

Hypothesis 5. There is a positive relationship between the marketing knowledge of the schools and universities and marketing decisions and results (of the schools and universities).

\subsection{Hypothesized model}

Previously stated hypotheses are shown in Figure 2. The model shows that knowledge is transferred in accordance with "snowball effect" among the marketing ambassadors; it also shows that marketing knowledge on the level of government, organisations and S\&U, influence the country development. In addition, the model shows that marketing knowledge of government, organisations and schools and universities makes influence on marketing decisions and results.

$58 \quad$ Rakić Mira, Rakić Beba (2014): “Integrated marketing r (e)volution in Serbia”, Conference proceedings: SMEs development and innovation: building competitive future of SouthEastern Europe, International conference - SMEs development and innovation: building competitive future of South-Eastern Europe, Faculty of economy - Prilep, Ohrid. 
Figure 2: Hypothesized model

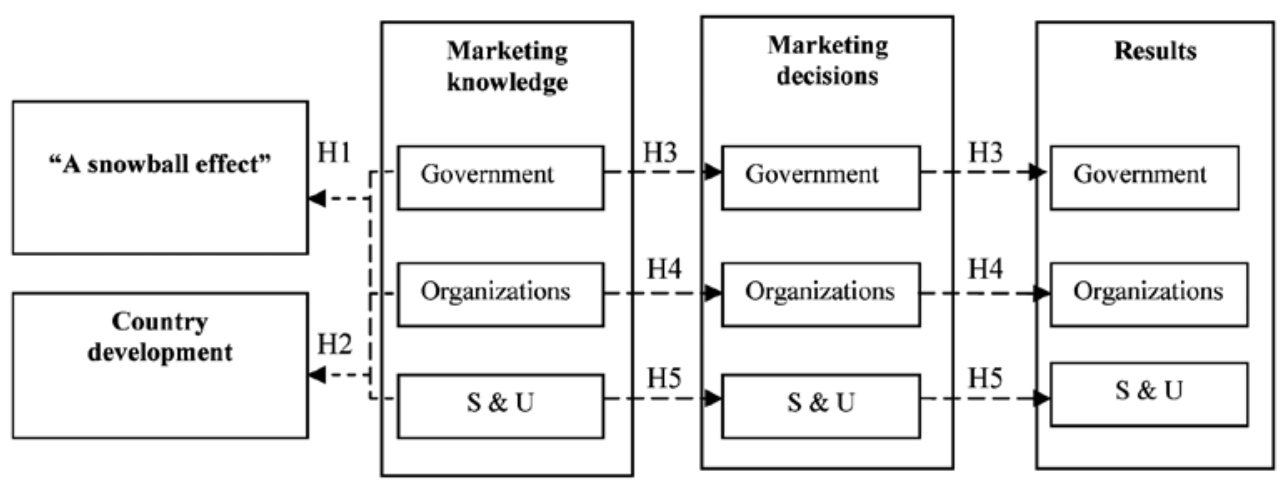

\section{Method}

The sample for this survey consisted of 30 marketing managers, 10 employees in the government (Ministry of Finance and Economy, Ministry of Education, Science and Technological Development, Ministry of Foreign Affairs), 10 professors of marketing and 10 students in doctoral studies (on the course: marketing management) in Serbia. Thirty-eight participants (63.3\%) were females and $22(36.7 \%)$ were males. Of those who provided their age, participants were 35.87 of age on average. A greater number of participants (71.7\%) have more than 10 years of experience.

In the first part of the survey, participants were asked: Is marketing knowledge transferred like "a rolling snowball" among the marketing ambassadors on the level of country, organisations, schools and universities? In the second part of questionnaire, the focus was on question: Whether the implementation of marketing knowledge changes at the level of country, organisations, schools and universities can influence the country development? In the third part of the questionnaire, the focus was on influence of marketing knowledge of the government to marketing decisions and results (of government). The fourth part of the questionnaire should answer the question - Whether marketing knowledge of organisations makes influence on marketing decisions and results (of organisations)? And the fifth - Whether marketing knowledge of schools and universities makes influence on marketing decisions and results (S\&U)? The last - sixth part included general demographic questions.

All variables were assessed on a 5 -point Likert scale (ranging from $1=$ strongly disagree, $2=$ disagree, $3=$ neither agree nor disagree, $4=$ agree, to $5=$ strongly agree). 


\section{Results}

Hypothesis 1. Mean scores ranging from 1 to 5 show that most participants (4.3) agree that the level of marketing knowledge is transferred like "a rolling snowball" among certain levels. As expected, the mean score for the transfer of marketing knowledge reported by professors (4.7) was greater than by managers (4.2) and by government representatives (4.1). However, some marketing managers experienced scepticism about the value and power of marketing knowledge of professors and students. Some marketing managers consider that the problem lies in the fact that marketing knowledge, which is required for practice, is not created in schools and universities. Several participants in organisations and government pointed out that graduated students „come with theoretic knowledge, insufficiently prepared for practice“, and that they have to „invest time and educate them additionally“. Several of them emphasized that ,ignorance is transferred and enhanced“. Some of them asked us: What is marketing knowledge?

Hypothesis 2. The majority of respondents consider that the implementation of marketing knowledge on the level of government, organisations, schools and universities can influence the country development $(\mathrm{M}=4.4)$. However, similarly to the previous hypothesis, the majority of practitioners (in organisations and government) added that the required practical marketing knowledge was missing.

Hypothesis 3. The majority of respondents $(\mathrm{M}=4.5)$ agree that marketing knowledge of government can influence marketing decisions and results of government. Compared to managers $(M=4.0)$ and professors and students $(M=$ 4.7), the representatives of the government value more the influence of marketing knowledge of government on decisions and results $(M=4.8)$. Managers, students and professors added that the government did not implement the strategy of positioning, but that it should do that

Hypothesis 4. Respondents consider that marketing knowledge of organisations makes influence on marketing decisions and results (of organisations) $(\mathrm{M}=4.6)$.

Hypothesis 5. Also, the majority $(M=4.5)$ agree that marketing knowledge of schools and universities makes influence on marketing decisions and results (of schools and universities).

\section{Discussion and conclusions}

The results of the present survey support hypothesis about power of marketing knowledge. Clearly, the findings show the relationship among: marketing knowledge of government, organisations and S\&U; and the 
relationship among marketing knowledge, decisions and results. Respondents agree that marketing knowledge represents an opportunity and that it can influence the development of countries, organisations, schools and universities. However, the majority of practitioners pointed out the threat - incompliance of academic and practitioner marketing knowledge. The conclusion follows, in order not to transfer "ignorance" or insufficiently useful knowledge, in order not to waste time and energy of professors and students in the creation of useless knowledge for practice, it is necessary to mutually specify useful knowledge. Relevant ministries, associations and institutes could gather and direct activities of the marketing ambassadors.

Holistic implementation of knowledge of the marketing ambassadors has the key role in the development of countries and organisations. Development is a result of the complementary effects of the integrated knowledge in different fields. The main role of knowledge is directing the economy, organizations and individuals. Integrated knowledge allows understanding of the necessity and significance of changes; development and implementation of strategies. Marketing knowledge is of particular importance.

Integrated knowledge should enable the definition and implementation of strategies:

- education;

- diversified economy;

- positioning of the country;

- marketing of all organizations.

Key recommendations - basics of the positioning and the factors that influence the image of the country are:

- Exports - The government should determine the key development sectors of the diversified economy, assist organizations in creating wellknown brands on the global market, which would enable the increase of exports and improvement of the image of the country;

- Government - it is necessary to build the image of professional, accountable, democratic government; establish and maintain relationships with key stakeholders in the international economic and political environment;

- Culture and heritage, tourism - with good promotion of culture and heritage, it is possible to attract tourists. However, before the promotion, investments are necessary in infrastructure, defining and implementation of a strategy for development of tourism.

- People - the government and educational organizations should make it possible to improve the expertise of people, and organizations can contribute to staff motivation. The government should explain the necessity and importance of applying the strategy of positioning the country 
and affect all stakeholders to contribute to positioning. These measures would additionally affect the expertise of the employees and kindness of the population.

- Investment and immigration - with facts stated above and other measures and actions, the government can encourage direct foreign investments and the arrival of students and business people. $.^{59} / 60$

Organization's acceptance and implementation of marketing mindset in business can "win" the consumers, create profits and ensure market survival. To respond to changes in business environment, and/or participate in their creation, or to survive in the process of globalization and digitalisation, marketing managers must define and implement marketing strategies, and the government should define and implement a strategy of positioning the country.

So, we can put the next question: does marketing knowledge enable slow or fast changes? Evolution or revolution in marketing? The answer to the question: evolution or revolution is evolution. Given that "the future is embedded in the present" ${ }^{\prime}$, i.e. starting with the existing situation, "immediate and prompt" marketing revolution is not possible. The understanding of the necessity, the determination and implementation of changes takes a long time. The changes need:

- human resources - multidisciplinary knowledge - skilled and motivated people - leaders with a vision, who have the knowledge, power and desire to direct government ministries, organizations, institutions and residents towards the implementation of defined strategies and development programs; managers, employees and residents;

- leaders at all levels, who understand the necessity and significance of the changes, have the knowledge, power and motivation to join together skilled people and create multidisciplinary teams;

- definition and implementation of strategies for co-creating, positioning and differentiation at all levels; implementation of marketing, both in organizations and at the country level and, on the basis of that, definition and implementation of the strategy of positioning of the organizations and country (emphasis on the development strategy of diversified economy);

- money - to invest in the development of diversified economy, development projects and programs, development of brands of goods/services/ organizations and creation and maintaining a good image of country, and Anholt Somon (2007): "The Anholt Nation Brand Index - Special Report Q2", GMI.

${ }^{60}$ Rakić Mira, Rakić Beba (2014): “Integrated marketing $\mathrm{r}$ (e)volution in Serbia”, Conference proceedings: SMEs development and innovation: building competitive future of SouthEastern Europe, International conference - SMEs development and innovation: building competitive future of South-Eastern Europe, Faculty of economy - Prilep, Ohrid.

${ }_{61}$ Nesbit Džon (2009): Mentalni sklop - Promeni okvir i sagledaj budućnost. Beograd: Megatrend univerzitet. 
- time (for initiating and implementing the changes). ${ }^{62}$

Why most managers do not manage change effectively? Often because they forget that the organization does not change, but the (behavior of) people who are in the organization. In order to achieve the changes, it is necessary for people in the organization to understand the necessity and significance of the. ${ }^{63}$

For successful implementation strategies, we need leaders, professional staff, investment and time. The last and the most important, the marketing ambassadors, together - on a basis of common activities (e.g. projects) can contribute to the creation, implementation and exchange of marketing knowledge, with positive results on certain levels and to the country development.

\section{Limitations and future research}

Although the results of survey show the significance of holistic implementation of knowledge of the marketing ambassadors, there are several limitations. Firstly, future studies should provide an opportunity for marketing actors to define marketing knowledge and specify key marketing decisions. In this survey, certain key marketing decisions were the starting point. We had to explain to some participants what some decisions meant (e.g. co-creating of unique value) and why these were stated, and not some others. Secondly, gaps have been noticed between theorists and practitioners, between giving the significance to theory and practice. These mentioned gaps and some others as well could also be the subject of a survey. Considering that knowledge is transferred, common defining of required and useful knowledge (by marketing ambassadors, at all levels) is necessary. Thirdly, a comparative analysis of significance of holistic implementation of marketing knowledge in several countries would be of special importance.

Future surveys can be oriented to methods of gathering and mutual work of the marketing ambassadors with the aim of creating useful marketing knowledge (for all marketing ambassadors).

62 Rakić Mira, Rakić Beba (2014): “Integrated marketing r (e)volution in Serbia”, Conference proceedings: SMEs development and innovation: building competitive future of SouthEastern Europe, International conference - SMEs development and innovation: building competitive future of South-Eastern Europe, Faculty of economy - Prilep, Ohrid.

63 Grey John (2004): “Ch-ch-ch-changes”, Canadian Business, 77(14-15): 93. 


\section{Literature}

- Ankers Paul, Brennan Ross (2002): „Managerial relevance in academic reserach: an exploratory study", Marketing Intelligence \& Planning 20(1), 15-21.

- Anholt Somon (2005a): “Editor's foreword”, Place Branding 1(4), 333-346.

- Anholt Somon (2005b): "Plug into your national brand", International Trade Forum, 20-23.

- Anholt Somon (2007): “The Anholt Nation Brand Index - Special Report Q2", GMI.

- Barac Nada (1994): “Marketing logistika i informacioni i komunikacioni sistemi”, Ekonomika, 40(5): 54-60.

- Bennis Warren, O’Toole James (2005): “How business schools lost their way", Harvard Business Review, 83(5): 96-104.

- Blocker Christopher et. Al. (2011): "Proactive customer orientation and its role for creating customer value in global markets", Journal of the Academy of Marketing Science, 39(2): 216-233.

- Brodie Roderick, Coviello Nicole, Bliemel Friedhelm (2003): "Introduction to the Special Issue on Conceptual Developments in Relationship Marketing", Marketing Theory, 3(1): 5-7.

- Brodie Roderick, Sharma, Rahul (2011): "National branding for New Zealand Exports", Marketing Theory, 14(1): 7-17.

- Buha Vesna, Janičić Radmila, Filipović Vinka, Gligorijević Mirjana (2011): "Virtuelna realnost u obrazovanju na daljinu i marketinškim komunikacijama”, Management - časopis za teoriju i praksu menadžmenta, 16(60): 51-59.

- Dibb Sally, Simkin Lyndon (2003): "Marketing educators: addressing implementation in core courses", Journal of Strategic Marketing, 11(1): 3-13.

- Durme Joel, Brodie Roderick, Redmore David (2003): "Brand Equity in Cooperative Business Relationships: Exploring the Development of a Conceptual Model”, Marketing Theory, 3(1): 37-57.

- Feiertag Howard (1997): "Relationship selling works only when practiced", Hotel \& Motel Management, 212(6): 18.

- Filipović Vinka (1994): "Marketing i upravljanje sistemom kvaliteta", Marketing, 25(4):57-62.

- Foley Anthony, Fahy John (2009): “Seeing market orientation through a capabilities lens", European Journal of Marketing, 43(1-2): 13-20.

- Gilmore F. (2002): "A country - can it be repositioned? Spain - the success story of country branding", Journal of Brand management, 9(4-5): 281-93.

- Grey John (2004): “Ch-ch-ch-changes”, Canadian Business, 77(14-15): 93.

- Gronhaug Kjell (2002): "Is marketing knowledge useful”, European Journal of Marketing, 36 (3): 364-372. 
- Grönroos Christian (1997): "From marketing mix to relationship marketing - towards a paradigm shift in marketing", Management Decision, 35(3-4): 322-339.

- Hanvanich Sangphet, Dröge Cornelia, Calantone Roger (2003): “Reconceptualizing the meaning and domain of marketing knowledge", Journal of Knowledge Management, 7(4): 124 - 135.

- Hirono Ryokichi (2003): "Reorienting international development to accelerate poverty reduction and ensure sustainability as this century's top development goals", International Review for Environmental Strategies, 4(1): 21-44.

- Kohli Ajay, Jaworski Bernard (1990): "Market orientation: the construct, research propositions and managerial implications", Journal of Marketing, 54(2): 1-18.

- Kotler Philip, Gertner David (2002): "Country as brand, product, and beyond: a place marketing and brand management perspective", Brand Management, 9(4-5): 249-61.

- Lafferty Barbara, Hult Tomas (2001): "A synthesis of contemporary market orientation", European Journal of Marketing, 35(1-2): 92-109.

- Lee Hanjoon, Acito Frank, Day Ralph (1987): "Evaluation and use of marketing research by decision makers: a behavioral simulation", Journal of Marketing Research, 24(2): 187-196.

- Levitt Theodore (1960): "Marketing myopia", Harvard Business Review, 38(4): 45-56.

- Milisavljević Momčilo (2005): “Tržišna orijentacija i poslovni uspeh preduzeća”, Megatrend revija, 2(2): 151-165.

- Narver John, Stanley Slater (1990): "The effect of a market orientation on business profitability", Journal of Marketing, 54(4): 20-35.

- Nesbit Džon (2009): Mentalni sklop - Promeni okvir i sagledaj budućnost. Beograd: Megatrend univerzitet.

- November Peter (2008): “Marketing knowledge myopia”, European Business Review, 20(5): 434-456.

- Osborne Phil, Ballantyne David (2012): “The paradigmatic pitfalls of customer-centric marketing", Journal of Marketing Theory \& Practice, 12(2): 155-172.

- Ottesen Geir, Gronhaug Kjell (2004): "Barriers to practical use of academic marketing knowledge”, Marketing Intelligence \& Planning, 22(5): 520-30.

- Pels Jaqueline, Coviello Nicole, Brodie Roderick (2000): “Integrating transactional and relational marketing exchange: a pluralistic perspective", Marketing Theory, 8(3): 11-19. 
- Plewa Carolin, Quester Pascale, Baaken Thomas (2005): "Relationship marketing and university-industry linkages: A conceptual framework", Marketing Theory, 5(4): 443-456.

- Pongsakornrungsilp Siwarit, Schroeder Jonathan (2011): “Understanding value co-creation in a co-consuming brand community", Marketing Theory, 11(3): 303-324.

- Prahalad C.K., Krishnan M.S. (2008): The new age of innovation - driving co-created value through global networks. USA: McGraw Hill.

- Prahalad C.K., Ramaswamy Venkatram (1999): Co-opting customer competence", Harvard Business Review, 78(1): 79-87.

- Prahalad C.K., Ramaswamy Venkatram (2004): The future of competition - co-creating unique value with customers, Boston: Harvard Business School Publishing.

- Raaij Erik, Stoelhorst J.W. (2008): “The implementation of a market orientation: A review and integration of the contributions to date", European Journal of Marketing, 42(11-12): 1265-1293.

- Rakić Mira, Rakić Beba (2014): "Integrated marketing r (e)volution in Serbia”, Conference proceedings: SMEs development and innovation: building competitive future of South-Eastern Europe, International conference - SMEs development and innovation: building competitive future of South-Eastern Europe, Faculty of economy - Prilep, Ohrid.

- Reinert Erik (2006): Globalna ekonomija - Kako su bogati postali bogati i zašto siromašni postaju siromašniji, Beograd: Čigoja štampa.

- Sawhney Mohanbir, Parikh Deval (2001): "Where value lives in a networked world", Harvard Business Review, 79(1): 79-86.

- Sorrell Martin (2002): “Branding the nation”, Brand Strategy, 25(159): 13.

- Vasiljev Stevan, Salai Suzana (2000): "Marketing kao ključna komponenta poslovnog potencijala”, Strategijski menadžment, 4(1): 38-43.

- Wierenga Berend (2002): "On academic marketing knowledge and marketing knowledge that marketing managers use for decision-making", Marketing Theory, 2(4): 355-362.

- Žnideršić-Kovač Ružica, Marić Dražen, Salai Suzana, Grubor Aleksandar (2013): "Etičko ponašanje potrošača u marketingu", Anali Ekonomskog fakulteta u Subotici, 29: 65-79.

Paper received: October $30^{\text {th }}, 2014$

Approved for publication: November $18^{\text {th }}, 2014$
Rad primljen: 30. oktobar 2014. Odobren za štampu: 18. novembar 2014. 
Prof. dr Beba Rakić,

Fakultet za poslovne studije, Megatrend univerzitet, Beograd

Prof. dr Mira Rakić,

Fakultet za poslovne studije, Megatrend univerzitet, Beograd

\section{HOLISTIČKA PRIMENA ZNANJA "AMBASADORA MARKETINGA"}

\section{S a ž e t a k}

Svrha istraživanja - Članak akcentira ulogu znanja u oblasti marketinga u razvoju zemalja, organizacija, škola i univerziteta. Svrha je istraživanje moći znanja ambasadora marketinga i predlog modela za holističku primenu znanja.

Metodologija - Istraživanje putem ličnog intervjuisanja sprovedeno je na uzorku od 30 marketing menadžera, 10 zaposlenih u vladi, 10 profesora i 10 studenata na doktorskim studijama u Srbiji.

Rezultati istraživanja - ambasadori marketinga - profesori, studenti, praktičari, ministri i svi zaposleni u oblasti marketinga, svojim marketinškim znanjima i veštinama, mogu da doprinesu razvoju škola, univerziteta, organizacija i zemalja.

Praktični doprinos - Postoji potreba da se stvara, razmenjuje i primenjuje znanje u oblasti marketinga na svim nivoima - od škola i univerziteta, putem organizacija, do ministarstava vlade. Ambasadori marketinga, na osnovu zajedničkih aktivnosti (npr. projekata) mogu da doprinesu stvaranju, primeni i razmeni znanja u oblasti marketinga, pozitivnim rezultatima na svim nivoima i razvoju zemlje.

Vrednost - Članak predstavlja holistički pristup stvaranju i razmeni znanja.

Ključne reči: marketing, znanja u oblasti marketinga, ambasadori marketinga, holistički marketing 
